\title{
Angiographic Morphometry of Internal Carotid Artery Circulation in Turkish Children
}

\section{Türk Çocuklarmda Internal Karotid Arter Dolaşımmnn Anjiyografik Morfometrisi}

\author{
Yonca Ozkan ARAT ${ }^{1,2}$, Anil ARAT $^{3}$, Kubilay AYDIN ${ }^{4}$ \\ ${ }_{1}^{1}$ Baskent University, Faculty of Medicine, Department of Ophthalmology, Ankara, Turkey \\ ${ }^{2}$ University of Wisconsin, Department of Ophthalmology and Visual Sciences, Madison, WI, USA \\ ${ }^{3}$ Hacettepe University, Department of Radiology, Section of Interventional Neuroradiology, Ankara, Turkey

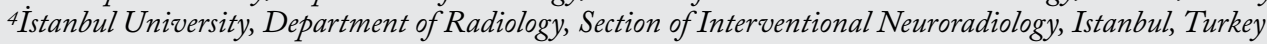

Corresponding Author: Anil ARAT / E-mail: anilarat@hotmail.com

\begin{abstract}
AIM: Knowledge of cerebrovascular morphology is integral in planning neuroendovascular interventions, especially for procedures involving placement of stents, flow diverters or stentrievers. There is insufficient data on angiographic normative values of cerebral circulation in the pediatric age group since angiograms are uncommonly performed in children except for arteriovenous malformations in which arterial dimensions are larger than normal. We aimed to measure the diameters of internal carotid circulation (ICC) arteries on digital subtraction angiograms of pediatric patients and determine the growth trends.
\end{abstract}

MATERIAL and METHODS: This is a retrospective cross-sectional study measurements of ICC arteries of 64 pediatric patients (4 - 122 months) with retinoblastoma undergoing intra-arterial chemotherapy.

RESULTS: Petrous, cavernous, supraclinoid and choroidal segments of internal carotid artery (ICA) and anterior cerebral artery (ACA) diameters had significant correlation with age. Most of the growth was noted in the first 36-48 months of life. Middle cerebral artery (MCA) diameter did not show significant correlation with age. $87 \%$ of the adult diameter of the MCA was attained in the first 6 months of life. ICC arteries reached $81 \%$ to $99 \%$ of adult sizes in the first 48 months of life. On the contrary, the main iliac artery was only $59 \%$ of the adult diameter at this age group.

CONCLUSION: Use of current intracranial stents in children appears tolerable due to the growth pattern of ICC arteries. Based on this data, the current armamentarium of intracranial stents or stent-like devices is sufficient to cover the need in the pediatric population.

KEYWORDS: Cerebral arteries, Internal carotid artery, Diameter, Endovascular treatment, Stent, Flow diverter, Morphometry

öz

AMAÇ: Nöroendovasküler girişimlerde, özellikle de stent, akım yönlendirici ve benzeri cihazlar kullanıldığında, serebrovasküler morfolojinin bilinmesi önemlidir. Serebral anjiyografi, arteryel boyutların normalden daha büyük olduğu arteriovenöz malformasyonlar dışında çocuklarda sık olarak yapılmadığından, pediatrik yaş gurubunda serebral dolaşımın anjiyografik normotif değerleri hakkında yeterli bilgi bulunmamaktadır. Çocuk hastalarda internal karotid dolaşımı (IKD) arterlerinin çaplarını ölçüp büyüme eğilimlerini belirlemeyi amaçladık.

YÖNTEM ve GEREÇLER: Çalışmamız, retinoblastom için intraarteryel kemoterapi yapılan 64 çocuk hastada (yaş: 4 - 122 ay) IKD arterlerinin ölçüldüğü retrospektif kesitsel bir çalışmadır.

BULGULAR: İnternal karotid arterin petröz, kavernöz, supraklinoid ve koroidal segmentleriyle anterior serebral arter (ASA) çapları yaş ile anlamlı korelasyon göstermekteydi. Damarsal büyümenin 36-48 ayda tamamlanmaya yaklaştığı saptandı. Orta serebral arter (OSA) çapı yaş ile anlamlı korelasyon göstermedi. Bu arterde ilk 6 ayda arteryel çapın \%87'sine ulaşıldığı izlendi. IKKD arterlerinin 48 ay itibarıyla erişkin boylarının \% 81-99'una ulaştığı görüldü. Bunun aksine ana iliak arter bu yaş gurubunda erişkin çapının sadece \% 59'uydu.

SONUÇ: IKD arterleri küçük çocuklarda bile stent kullanımına izin verecek şekilde büyüme göstermektedir. Halihazırda erişkinlerde kullanılan stent ve benzeri cihazların boyutu pediatrik kullanımı da kapsayacak düzeydedir.

ANAHTAR SÖZCÜKLER: Serebral arterler, İnternal karotid arter, Çap, Endovasküler tedavi, Stent, Akım yönlendirici, Morfometri

\section{INTRODUCTION}

Knowledge of cerebrovascular dimensions is crucial for the performance of neurovascular procedures (28). Angiographic normative data about the diameters of cerebral arteries in adults is reported in detail in the literature $(19,24,28,32$,
34) with endovascular instruments such as stents being manufactured based on these measurements. On the other hand, normative values and growth trends of these vessels are largely unknown in the pediatric age group. 
In the pediatric population, brain arteriovenous malformation embolizations have been the flagship of neurointerventional procedures. In spite of its relative paucity, endovascular treatment of pediatric cerebral aneurysms has been performed for more than 25 years and is becoming increasingly more common (4). As endovascular aneurysm treatment shifted towards more liberal use of endoluminal prostheses such as stents and flow diverters, a need for better knowledge of angiographic measurements of cerebral artery diameters emerged as these devices rely on meticulous measurement of the diameter of the artery harboring the aneurysm (28). Due to the direct relation of arterial size with vascular demand, normative arterial diameters cannot be inferred from angiograms performed on children for the treatment of high flow lesions (such as arteriovenous malformations or hypervascular tumors) that are the forerunners of referrals for pediatric cerebral angiograms. In the mean time, intraarterial chemotherapy for retinoblastoma, a lesion outside the brain with negligible arterial demand (vascular blush), has been on the rise for the last 5 years and has become an established therapy for advanced intraocular retinoblastoma in many centers (14). We observed that the cerebral angiography performed as a part of this treatment provides a unique opportunity to examine normal cerebrovascular anatomy in small children.

In this study we aimed to measure the diameters of the main internal carotid circulation arteries on digital subtraction angiograms of pediatric patients with retinoblastoma undergoing intraarterial chemotherapy to determine the normative values of cerebral artery diameters. We also assessed the correlations of these cerebral artery diameters with the age of the patients.

\section{MATERIAL and METHODS}

Cerebral angiograms of children with retinoblastoma referred for intraarterial injection of chemotherapeutic agents were retrospectively identified and relevant arterial measurements were obtained on these angiograms.

\section{General Description of the Procedure}

In this retrospective cross-sectional study of cerebral angiographic measurements of 64 pediatric patients with retinoblastoma undergoing intraarterial chemotherapy, the procedures were performed by two endovascular specialists under general anesthesia and heparinization (70 to $100 \mathrm{mg} /$ $\mathrm{kg}$ IV push) and through a femoral arterial approach with a 21G needle. A biplane (Artis Zeego VC21A/B, Siemens, Erlangen, Germany) or uniplane (Artis Zeego, Siemens, Erlangen, Germany) angiography unit was used. A 4 F diagnostic catheter was placed directly through the common femoral artery and pelvic arteriograms in anteroposterior view were obtained with the field of view set to 22 centimeters and with injection of 4 to $6 \mathrm{ml}$ of nonionic iodinated contrast medium (most commonly Ultravist 300, Bayer Healthcare, Germany) in about 2 seconds to evaluate the femoral arteries. $0.4 \mathrm{ml}$ of Nimodipine (Nimotop, Bayer Healthcare, Germany) diluted to
1:50 with normal saline was injected into the ipsilateral external iliac artery to prevent vasospasm. The same catheter was used to access the internal carotid artery ipsilateral to the eye involved with retinoblastoma. Selective internal carotid angiograms in anteroposterior and lateral projections again with injection of 4 to $6 \mathrm{ml}$ of nonionic iodinated contrast medium in 2 seconds were obtained with the FOV set to 22 centimeters. A microcatheter (inner lumen of 0.015 to 0.0165 inch, most commonly SL10, Stryker Neuroendovascular, Kalamazoo, MI, USA) was navigated coaxially to the ophthalmic artery over a microguidewire (0.010 to 0.014 inch guidewire, such as Asahi 10, Asahi Intecc, Nagoya, Japan or Transend 14, Stryker Neuroendovascular, Kalamazoo, MI, USA). This artery was catheterized and superselective angiograms were obtained. $30 \mathrm{ml}$ of Melphalan solution (usually $5 \mathrm{mg}$ ) in saline was injected over 30 minutes. After infusion, the ophthalmic, internal carotid and femoral injections were repeated, the anticoagulation was reversed with intravenous administration of protamine sulfate, and femoral hemostasis was achieved by manual compression.

\section{Measurements}

Only the angiogram of the very first procedure for each patient was included in the study. The first side to be catheterized was chosen for the measurements if bilateral procedures were done in the same session. Measurements were performed on pelvic arteriograms for the common iliac artery, and on the internal carotid artery for segments of internal carotid, middle cerebral and anterior cerebral arteries. For all projections, measurements were calibrated with respect to the $4 \mathrm{~F}$ catheter using the automated software preloaded on the angiography systems. For the common iliac artery, measurements were obtained on the AP projection at a point $5 \mathrm{~mm}$ proximal to its bifurcation. For the petrous segment, the diameter was measured on the anteroposterior projection at the midpoint of the vertical subsegment of the petrous internal carotid artery (Figure 1A). For the cavernous, supraclinoid and choroidal segments, measurements were taken at the most rostral segment of the cavernous ICA, at the midpoint of the origins of the ophthalmic and anterior choroidal arteries and immediately distal to the choroidal artery origin respectively (Figure 1B) on the lateral projection. For both anterior cerebral and middle cerebral arteries, diameters were measured at a point $5 \mathrm{~mm}$ distal to the bifurcation of the ICA on the anteroposterior projection (Figure 1A). Correlations of these measurement variables with age were analyzed. Similar measurements were taken from 10 adult angiograms without any radiological sign of vessel wall lesions or pathological vessel changes, including vasospasm, vascular malformations, vasculitis or atherosclerosis.

The study group was divided into 6 age categories: 0-6 months, 6-12 months, 12-24 months, 24-48 months, 48-72 months, 72 months and above (72-127 months). The adult group included the measurements obtained from cerebral angiograms of 10 adults. The percentage of adult size obtained was calculated by the division of the mean value for the measurement 
variable in question by the mean value of the adult group. We added an adult group for comparison since there was no normative data in the literature regarding the diameters of the investigated vessels in the Turkish population.

\section{Statistical Analysis}

Statistical differences between two group means were tested by Student's $T$ test. Test statistics associated with probabilities of 0.05 or less were considered significant. Correlations of the measurement variables with age were determined by Pearson correlation coefficients (r). Growth trends of the artery diameters were analysed using Gompertz growth curves.

\section{RESULTS}

The subjects were grouped according to their age for analysis. (Table I). Differences in the diameters of arteries between the genders for the various measurement variables for all ages were not significant except for choroidal segment of the ICA $(p=0.021)$ and MCA ( $p=0.005)$, which were significantly wider in males. Since these differences were clinically insignificant ( $0.2 \mathrm{~mm}$ difference for choroidal segment of ICA and MCA) and were within the range that could be expected by chance alone, values for measurement variables were grouped and tabled only by age category. This study was not designed to evaluate for gender differences and as such, there was insufficient power to detect any possible differences.

The diameters of the internal carotid artery circulation in different age groups are shown in Table II. All segments of ICA (correlation is significant at the 0.01 level; $r=0,58$ for petrous segment, $r=0,52$ for cavernous segment, $r=0,44$ for supraclinoid segment, $r=0,33$ for choroidal segment) and ACA (correlation is significant at 0.05 level; $r=0,26$ ) diameter had a significant correlation with age (Table III). The most significant change in diameters was observed around the first 36-48 months of life (Figure 2). MCA diameter did not show significant correlation with age (Table III). The percentage of

Table I: Age Distribution of the Groups

\begin{tabular}{|l|c|c|c|r|r|r|}
\hline Group & No & Mean Age & SE Mean & StDev & Min & Max \\
\hline 1 (0-6 mo) & 5 & 5.0 & 0.3 & 0.7 & 4.0 & 6.0 \\
\hline 2 (6-12 mo) & 8 & 9.8 & 0.5 & 1.5 & 8.0 & 12.0 \\
\hline $3(12-24 \mathrm{mo})$ & 22 & 20.0 & 0.7 & 3.6 & 13.0 & 24.0 \\
\hline $4(24-48 \mathrm{mo})$ & 16 & 37.1 & 1.6 & 6.6 & 28.0 & 48.0 \\
\hline $5(48-72 \mathrm{mo})$ & 8 & 63.8 & 2.5 & 7.0 & 54.0 & 72.0 \\
\hline 6 (72 mo \& up) & 5 & 97.8 & 8.8 & 19.8 & 74.0 & 122.0 \\
\hline 7 (adults) & 10 & 573.6 & 35.0 & 110.7 & 396.0 & 732.0 \\
\hline
\end{tabular}

Abbreviations: mo: months, no: number of subjects, SE Mean: standart error of mean, StDev: standart deviation, min: minimum, max: maximum.

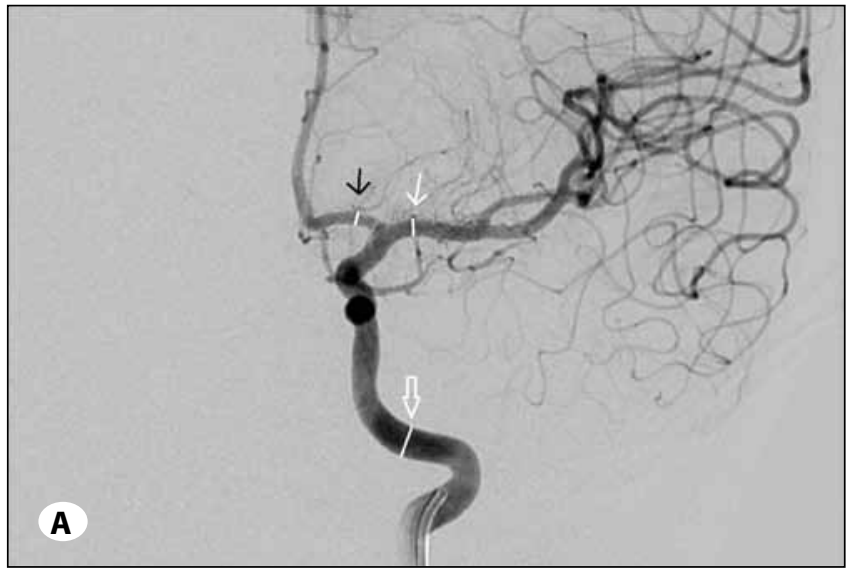

Figure 1: A) Carotid arteriogram in anteroposterior projection showing how measurements were performed at the petrous segment of the internal carotid artery (white open arrow), A1 segment of the anterior cerebral artery (black arrow) and M1 segment of the middle cerebral artery (white arrow). B) Carotid angiogram in lateral projection demonstrating the measurements of the choroidal segment (white open arrow), supraclinoid segment (black open arrow) and cavernous segment (black arrow) of the internal carotid artery.

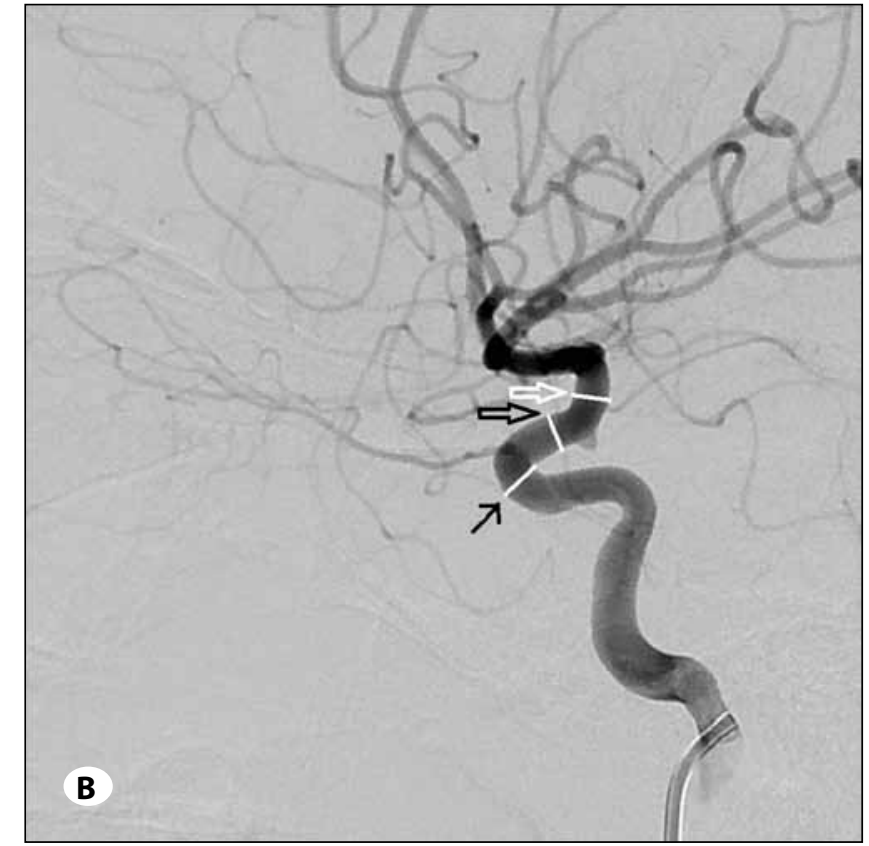


Table II: Diameters of Different Segments of Internal Carotid Artery, Middle and Anterior Cerebral Artery in Different Age Groups

\begin{tabular}{|c|c|c|c|c|c|}
\hline Age Groups & Mean & SE Mean & SD & Minimum & Maximum \\
\hline \multicolumn{6}{|l|}{ ICA } \\
\hline \multicolumn{6}{|l|}{ Petrous } \\
\hline 1 (0-6 mo) & 2.92 & 0.14 & 0.32 & 2.50 & 3.30 \\
\hline 2 (6-12 mo) & 3.55 & 0.15 & 0.41 & 3.00 & 4.20 \\
\hline 3 (12-24 mo) & 3.70 & 0.11 & 0.52 & 2.80 & 4.90 \\
\hline $4(24-48 \mathrm{mo})$ & 3.94 & 0.14 & 0.54 & 3.20 & 5.60 \\
\hline 5 (48-72 mo) & 3.96 & 0.18 & 0.50 & 3.40 & 4.80 \\
\hline 6 (72 mo\&up) & 4.54 & 0.13 & 0.28 & 4.10 & 4.80 \\
\hline 7 (adults) & 4.88 & 0.18 & 0.56 & 4.30 & 5.80 \\
\hline \multicolumn{6}{|l|}{ Cavernous } \\
\hline 1 (0-6 mo) & 2.96 & 0.10 & 0.23 & 0.27 & 3.30 \\
\hline 2 (6-12 mo) & 3.31 & 0.14 & 0.38 & 2.60 & 3.70 \\
\hline 3 (12-24 mo) & 3.50 & 0.08 & 0.39 & 2.70 & 4.20 \\
\hline 4 (24-48 mo) & 3.82 & 0.11 & 0.44 & 3.30 & 4.50 \\
\hline 5 (48-72 mo) & 3.68 & 0.12 & 0.35 & 3.20 & 4.20 \\
\hline 6 (72 mo\&up) & 4.28 & 0.23 & 0.52 & 3.50 & 4.70 \\
\hline 7 (adults) & 4.41 & 0.23 & 0.73 & 3.60 & 5.50 \\
\hline \multicolumn{6}{|l|}{ Supraclinoid } \\
\hline 1 (0-6 mo) & 2.82 & 0.14 & 0.31 & 2.50 & 3.30 \\
\hline 2 (6-12 mo) & 3.05 & 0.11 & 0.32 & 2.50 & 3.60 \\
\hline 3 (12-24 mo) & 3.19 & 0.07 & 0.35 & 2.50 & 3.80 \\
\hline $4(24-48 \mathrm{mo})$ & 3.32 & 0.05 & 0.22 & 3.00 & 3.70 \\
\hline 5 (48-72 mo) & 3.23 & 0.14 & 0.41 & 2.70 & 3.80 \\
\hline 6 (72 mo\&up) & 3.66 & 0.19 & 0.42 & 3.00 & 4.10 \\
\hline 7 (adults) & 3.68 & 0.20 & 0.64 & 2.80 & 4.60 \\
\hline \multicolumn{6}{|l|}{ Choroidal } \\
\hline 1 (0-6 mo) & 2.62 & 0.12 & 0.28 & 2.20 & 2.90 \\
\hline 2 (6-12 mo) & 2.84 & 0.11 & 0.32 & 2.30 & 3.40 \\
\hline 3 (12-24 mo) & 3.01 & 0.07 & 0.36 & 2.50 & 3.70 \\
\hline 4 (24-48 mo) & 3.13 & 0.08 & 0.34 & 2.70 & 3.90 \\
\hline 5 (48-72 mo) & 3.08 & 0.14 & 0.40 & 2.50 & 3.70 \\
\hline 6 (72 mo\&up) & 3.44 & 0.14 & 0.32 & 3.00 & 3.80 \\
\hline 7 (adults) & 3.33 & 0.16 & 0.51 & 2.80 & 4.30 \\
\hline \multicolumn{6}{|l|}{ MCA } \\
\hline 1 (0-6 mo) & 2.34 & 0.10 & 0.22 & 2.10 & 2.50 \\
\hline 2 (6-12 mo) & 2.48 & 0.15 & 0.42 & 1.90 & 3.30 \\
\hline 3 (12-24 mo) & 2.59 & 0.06 & 0.28 & 2.10 & 3.20 \\
\hline 4 (24-48 mo) & 2.68 & 0.08 & 0.33 & 2.20 & 3.20 \\
\hline 5 (48-72 mo) & 2.74 & 0.11 & 0.32 & 2.30 & 3.20 \\
\hline 6 (72 mo\&up) & 2.72 & 0.11 & 0.24 & 2.40 & 3.00 \\
\hline 7 (adults) & 2.68 & 0.11 & 0.36 & 2.20 & 3.30 \\
\hline \multicolumn{6}{|l|}{ ACA } \\
\hline 1 (0-6 mo) & 1.70 & 0.03 & 0.07 & 1.60 & 1.80 \\
\hline 2 (6-12 mo) & 1.96 & 0.13 & 0.37 & 1.40 & 2.70 \\
\hline 3 (12-24 mo) & 2.10 & 0.06 & 0.26 & 1.50 & 2.70 \\
\hline 4 (24-48 mo) & 2.16 & 0.09 & 0.37 & 1.50 & 3.00 \\
\hline 5 (48-72 mo) & 1.94 & 0.22 & 0.62 & 1.20 & 3.00 \\
\hline 6 (72 mo\&up) & 2.14 & 0.19 & 0.43 & 1.90 & 2.90 \\
\hline 7 (adults) & 2.30 & 0.14 & 0.43 & 1.90 & 3.30 \\
\hline
\end{tabular}

Abbreviations: ICA: internal carotid artery, OA: ophthalmic artery, MCA: middle cerebral artery,SD: standart deviation, SE Mean: standart error of mean. 
adult sizes attained in the first 48 months of life ranged from $81 \%$ to $94 \%$ for all segments of ICA and ACA, was $99 \%$ for MCA and $59 \%$ for common iliac artery. The percentage values of the adult vascular diameter attained at different age groups are shown in Table IV. The growth trends of the vascular diameters analyzed by Gompertz growth curves are shown in Figure 2.

\section{DISCUSSION}

Detailed knowledge of cerebrovascular morphology is integral in planning the treatment and assessing device performance for endovascular interventions (41). Mean internal diameter of cerebral arteries and vascular geometry are important in diagnosis and management of cerebral aneurysms, strokes and ischemia (17).

Up to $6.8 \%$ of all intracranial aneurysms arise in the pediatric age group (31). In addition, embolic strokes in children and their endovascular treatment have been reported recently $(1,39)$. A definite subset of children with aneurysms and embolic stroke would require endovascular management with stents or stent-like devices that rely on accurate vascular morphometric measurements for placement. There is lack of data in the literature regarding the morphometry of internal carotid circulation in the pediatric age group. The existing data for adults comprises of CT or MR angiograms and to some extent digital subtraction angiograms, which are the gold standard for imaging-based measurements (11). Cadaveric studies have some morphometric limitations including measurement of external diameter of the vessels
(41). We were unable to find a pediatric series focusing on the angiographic measurements based on modern digital subtraction angiography.

Based on our findings, the arterial diameters appear to follow the size of the brain territory they supply. It is shown that the brain reaches $90 \%$ of its adult size by the first year of age while its complete growth ends at age 7 (22). A 3D MRI study of brain development during infancy and childhood showed that growth spurts of the whole brain as well as frontal and temporal lobes were noted during the first two years after birth. (23). Similarly, Waitzman et al. (35), showed that the cranium grew rapidly in the first year of life and the growth slowed markedly in the later years and was almost complete by age 6 . In our study, we noted that diameters of all segments of ICA and ACA had a significant correlation with age. Most of the growth was noted around 36-48 months of life and this appeared to be parallel with the brain growth $(22,23,35)$. We also noted that MCA diameter did not show significant correlation with age. For MCA the adult size was attained almost fully (87\%) in the first 6 months of life. Additionally, Matsuzawa et al. (23), showed that during the first 2 years of life where growth spurts of the brain was seen, the frontal lobes grew more rapidly than the temporal lobes. These might explain why we observed significant correlation with age in ACA diameters but not in MCA diameters. Another finding was that the iliac artery reached only $59 \%$ of adult the diameter in the first 48 months of life. This is in contrast with all the segments of ICA circulation where $81 \%$ to $99 \%$ of adult diameters are attained by 48 months of age.

Table III: Correlation Matrix of Different Segments of Internal Carotid Artery, Iliac Artery, Anterior and Middle Cerebral Artery Diameters with Age

\begin{tabular}{c|c|c|c|c|c|c|c|c|c|c|}
\multicolumn{2}{c|}{} & Age (mo) & $\begin{array}{c}\text { ICA- } \\
\text { petrous }\end{array}$ & $\begin{array}{r}\text { ICA- } \\
\text { cavernous }\end{array}$ & $\begin{array}{r}\text { ICA- } \\
\text { supraclinoid }\end{array}$ & $\begin{array}{c}\text { ICA- } \\
\text { choroidal }\end{array}$ & MCA & ACA \\
Age & $\mathrm{r}$ & 1 & $.588^{* *}$ & $.519^{* *}$ & $.443^{* *}$ & $.325^{* *}$ & .117 & $.261^{*}$ & $.698^{* *}$ \\
& $\mathrm{P}$ & & .000 & .000 & .000 & .005 & .322 & .025 & .000 \\
\hline
\end{tabular}

Abbreviations: mo: month, ICA: internal carotid artery, MCA: middle cerebral artery, ACA: anterior cerebral artery.

Table IV: Percentage of the Adult Diameter Attained at Different Age Groups for Internal Carotid Artery, Iliac Artery, Anterior and Middle Cerebral Artery

\begin{tabular}{|c|c|c|c|c|c|c|c|}
\hline Group & ICA-petrous & $\begin{array}{c}\text { ICA- } \\
\text { cavernous }\end{array}$ & $\begin{array}{c}\text { ICA- } \\
\text { supraclinoid }\end{array}$ & $\begin{array}{c}\text { ICA- } \\
\text { choroidal }\end{array}$ & MCA & ACA & Iliac artery \\
\hline 1 (0-6 mo) & 60 & 67 & 76 & 79 & 87 & 74 & 36 \\
\hline 2 (6-12 mo) & 73 & 75 & 83 & 85 & 92 & 85 & 40 \\
\hline 3 (12-24 mo) & 76 & 79 & 86 & 90 & 96 & 91 & 47 \\
\hline 4 (24-48 mo) & 81 & 86 & 90 & 94 & 99 & 93 & 59 \\
\hline 5 (48-72 mo) & 81 & 83 & 88 & 92 & 100 & 94 & 63 \\
\hline 6 (72 mo\&up) & 93 & 97 & 99 & 100 & 100 & 93 & 77 \\
\hline
\end{tabular}

Abbreviations: mo: month, ICA: internal carotid artery, MCA: middle cerebral artery, ACA: anterior cerebral artery. 

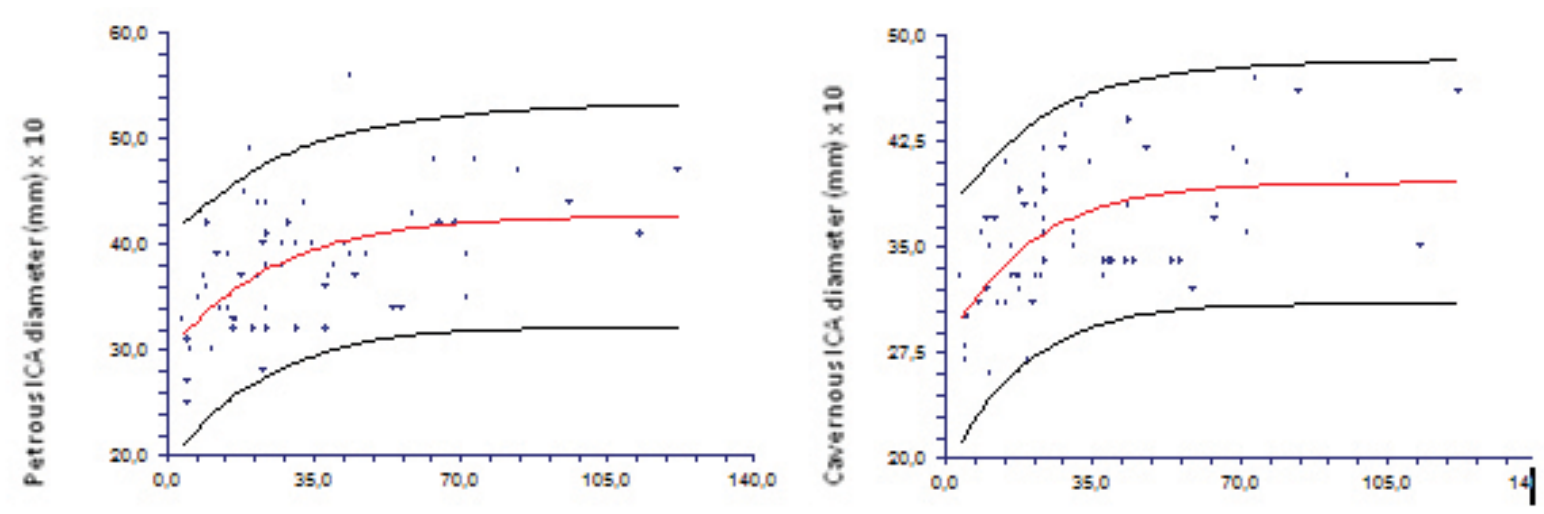

Age (MIonths)

Age (Mlonths)
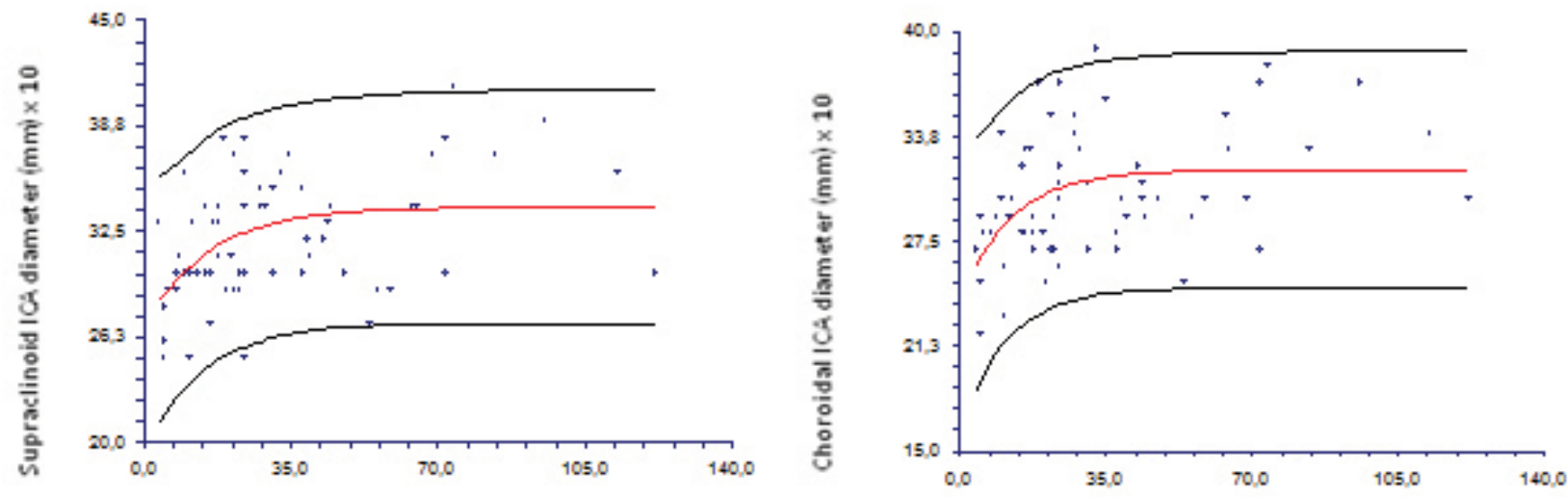

Age (M.lonths)

Age (M.lonths)

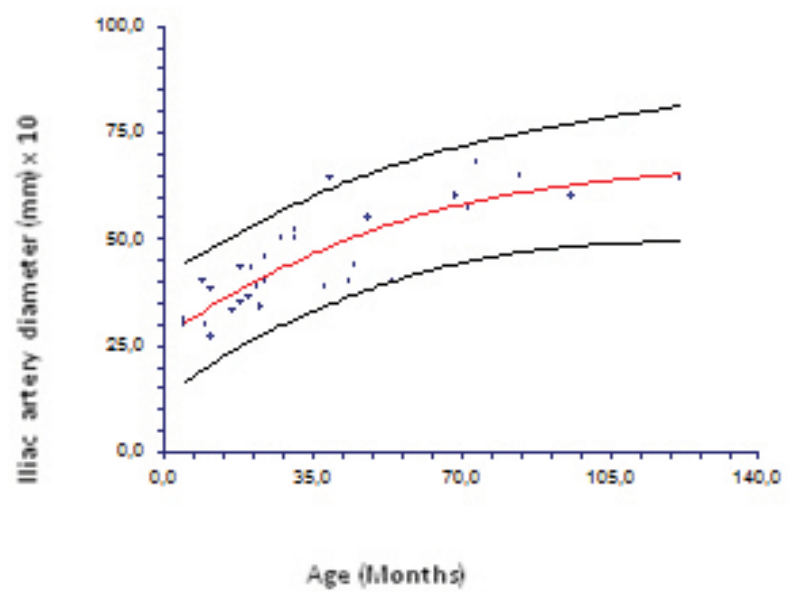

Figure 2: Growth trends of different segments of internal carotid artery, anterior and middle cerebral artery with age. (ICA: internal carotid artery). 
Besides the pediatric intracranial arterial measurements using modern angiographic equipment, we included 10 adults for related measurements. Our limited adult group yielded measurements similar to the published literature. We included this group for comparison since we were not able to find normative data regarding the carotid and cerebral artery diameters in the Turkish population. Adult group ICA and cerebral artery diameters found in this study correlated well with values reported in the literature (37). Wollschlaeger et al. (37) reported angiographic measurements of $2.03 \mathrm{~mm}$ for ACA, $2.87 \mathrm{~mm}$ for MCA and $3.7 \mathrm{~mm}$ for ICA. A recent study on cerebrovascular geometry in the anterior circulation reported mean diameter of $5 \pm 0.6 \mathrm{~mm}$ and $3.6 \pm 0.4 \mathrm{~mm}$ for cavernous ICA and the ICA terminus measured with computed tomography angiography (28). They also reported mean diameters of $3.1 \pm 0.4 \mathrm{~mm}$ and $2.4 \pm 0 \mathrm{~mm}$ at the MCA and $\mathrm{M} 2$ origins respectively. They found no difference based on gender or side. The measurement of the arteries in these reports is somewhat similar to the magnetic resonance angiography findings of Krabbe-Hartkamp et al. (19). Our findings and those of Wollschlaeger et al. (37) in adults are based on selective angiography, the gold standard in vascular imaging and are more likely to indicate the actual values.

Our findings have some important clinical implications. Secondary to a gradual increase in the endovascular treatment of aneurysms in pediatric age group (16) as well as recent inclusion of children in intraarterial stroke treatments (3), stents and similar devices (stentrievers, flow diverters) which are used as common (or in certain cases as routine) endovascular devices $(1,10)$, are inevitably finding their use in the pediatric population. In the meantime, concerns have arisen regarding intracranial stent use in the pediatric age group due to unknown effect of stents on growing vessels $(3,20,29)$. Arnold et al. (3) implied that stents were contraindicated in children due to ongoing growth as well as the small sizes of the cerebral arteries. They also noted that specifically designed catheters were needed. The statements put forward by these authors in the corresponding articles were not supported by any morphometric references.

The results of our study demonstrate that abstinence from stenting in the intracranial circulation only based on size criteria and expected growth of vessels is not justified in children. We also propose that from a morphometric standpoint, the size range of current intracranial stents, stentrievers or flow diverters is sufficient to cover the pediatric population. Significantly smaller iliac diameters in children indicate the femoral access as the limiting factor. At times, this problem can be solved by using 3 French long introducer sheaths or directly $4 \mathrm{~F}$ diagnostic catheters for internal carotid artery access through a transfemoral route. In very young children, direct access with 2.4 to 3.4 French microcatheters at the groin may be possible for stent or flow diverter placement. In these cases, it would be preferable to have a stent delivery microcatheter with transitions adjusted for very small children, in a manner similar to the pediatric version of Baltacci catheter (Balt, Montmerci, France) manufactured specifically for retinoblastoma treatment. Apart from morphometric measurements, the more critical issues that need to be better clarified in children are the concerns about the long-term efficacy for flow diverters and patency or long term antiplatelet agent protocols for both stents and flow diverters.

We performed a literature search to see if our findings were supported by the current endovascular practice. We noted that in a great majority of single-center large series concerning stenting for intracranial aneurysms, an age range to include children was present $(12,26,27)$. However, no information specific to the sizing of the devices or antiplatelet drug administration in children was provided in these series. We were able to find 16 reports that clearly noted the sizes of intracranial stents or flow diverters used in a child $(2,5-9,13$, $15,18,20,21,25,30,36,38-40)$. The age range in these reports ranged from 9 months to 17 years (mean 10 years) and 6 of the cases were age 7 or below. The sizes of the devices used in these children matched the sizes of devices we would have used for similar locations in adult patients (e.g. $2.5 \mathrm{~mm}$ flow diverter for an $\mathrm{M} 1$ aneurysm, $4 \mathrm{~mm}$ flow diverter for a cavernous aneurysm, $4.5 \mathrm{~mm}$ stent for ICA dissection, $3 \mathrm{~mm}$ stent for MCA aneurysm). On the other hand, the antiplatelet regimen was not uniform. The procedures were carried out safely and issues related to change in arterial size of the growing children were not encountered in these reports.

To conclude, concerns relating to abstinence from stenting in children appear to hold true for the peripheral circulation rather than the intracranial circulation and the current armamentarium of intracranial stents or stent-like devices is sufficient to cover the need in the pediatric population. Notwithstanding the ability of current devices to cover the need in children, indication of such devices should rely on other data including but not limited to long-term efficacy and patency rates and the need for associated antiplatelet medications which is beyond the scope of this study.

\section{ACKNOWLEDGEMENTS}

The authors would like to acknowledge Prof. Fikret Gurbuz, Prof. Ensar Baspınar and research assistant Rabia Albayrak Delialioglu from the Department of Genetics and Statistics, Faculty of Agriculture, Ankara University, for their help in the statistical analysis of the study.

\section{REFERENCES}

1. Alnaami I, Buchholz H, Ashforth R, Yeo T, Kotylak T, Alaklabi $M$, Rutledge J: Successful use of Solitaire FR for stroke in a pediatric ventricular assist device patient. Ann Thorac Surg 96: e65-67, 2013

2. Appelboom G, Kadri K, Hassan F, Leclerc X: Infectious aneurysm of the cavernous carotid artery in a child treated with a new-generation of flow-diverting stent graft: case report. Neurosurgery 66: E623-624, 2010

3. Arnold $M$, Steinlin M, Baumann A, Nedeltchev K, Remonda L, Moser SJ, Mono ML, Schroth G, Mattle HP, Baumgartner RW: Thrombolysis in childhood stroke: report of 2 cases and review of the literature. Stroke 40: 801-807, 2009 
4. Asaithambi G, Adil MM, Shah KM, Jordan LC, Qureshi Al: Patterns of treatment and associated short-term outcomes of unruptured intracranial aneurysms in children. Childs Nerv Syst 30: 1697-1700, 2014

5. Binning MJ, Khalessi AA, Siddiqui AH, Hopkins LN, Levy El: Stent placement for the treatment of a symptomatic intracranial arterial dissection in an adolescent. J Neurosurg Pediatr 6: 154-158, 2010

6. Burrows AM, Zipfel G, Lanzino G: Treatment of a pediatric recurrent fusiform middle cerebral artery (MCA) aneurysm with a flow diverter. J Neurointerv Surg 5: e47, 2013

7. Chandela S, Alzate J, Sen C, Song J, Nimi Y, Berenstein A, Langer D: Treatment of a complex posterior fossa aneurysm in a child using side-to-side posterior inferior cerebellar artery-posterior inferior cerebellar artery bypass. J Neurosurg Pediatr 1: 79-82, 2008

8. Cohen JE, Ferrario A, Ceratto R, Miranda C, Lylyk P: Reconstructive endovascular approach for a cavernous aneurysm in infancy. Neurol Res 25: 492-496, 2003

9. Crowley RW, Evans AJ, Kassell NF, Jensen ME, Dumont AS: Endovascular treatment of a fusiform basilar artery aneurysm using multiple "in-stent stents". Technical note. J Neurosurg Pediatr 3: 496-500, 2009

10. D'Urso PI, Lanzino G, Cloft HJ, Kallmes DF: Flow diversion for intracranial aneurysms: A review. Stroke 42: 2363-2368, 2011

11. Ferguson SD, Rosen DS, Bardo D, Macdonald RL: Arterial diameters on catheter and computed tomographic angiography. World Neurosurg 73: 165-173, 2010

12. Fiorella D, Albuquerque FC, Han $P$, McDougall CG: Preliminary experience using the Neuroform stent for the treatment of cerebral aneurysms. Neurosurgery 54: 6-16, 2004

13. Fontela PS, Tampieri D, Atkinson JD, Daniel SJ, Teitelbaum J, Shemie SD: Posttraumatic pseudoaneurysm of the intracavernous internal carotid artery presenting with massive epistaxis. Pediatr Crit Care Med 7: 260-262, 2006

14. Gobin YP, Dunkel IJ, Marr BP, Brodie SE, Abramson DH: Intra-arterial chemotherapy for the management of retinoblastoma: four-year experience. Arch Ophthalmol 129: 732-737, 2011

15. Gupta V, Jain V, Mathuria SN, Khandelwal N: Endovascular treatment of a mycotic intracavernous carotid artery aneurysm using a stent graft. Interv Neuroradiol 19: 313-319, 2013

16. Hetts SW, Narvid J, Sanai N, Lawton MT, Gupta N, Fullerton HJ, Dowd CF, Higashida RT, Halbach VV: Intracranial aneurysms in childhood: 27-year single-institution experience. AJNR Am J Neuroradiol 30: 1315-1324, 2009

17. Kim DW, Kang SD: Association between internal carotid artery morphometry and posterior communicating artery aneurysm. Yonsei Med J 48: 634-638, 2007

18. Komiyama $M$, Yoshimura $M$, Honnda $Y$, Matsusaka $Y$, Yasui $T$ : Acute basilar artery dissection treated by emergency stenting in a 13-year-old boy. Pediatr Neurosurg 41: 318-322, 2005
19. Krabbe-Hartkamp MJ, van der Grond J, de Leeuw FE, de Groot JC, Algra A, Hillen B, Breteler MM, Mali WP: Circle of Willis: morphologic variation on three-dimensional time-of-flight MR angiograms. Radiology 207: 103-111, 1998

20. Lai YJ, Chang FC, Lin CJ, Hsieh TC, Wang KL: Endovascular therapy in pediatric intracranial carotid artery dissection. Pediatr Neurol 42: 291-294, 2010

21. Lee JY, Kwon BJ, Kang HS, Wang KC:Subarachnoid hemorrhage from a dissecting aneurysm of the posterior cerebral artery in a child: Rebleeding after stent-assisted coiling followed by stent-within-stent technique. J Korean Neurosurg Soc 49: 134-138, 2011

22. Likus W, Bajor G, Gruszczynska K, Baron J, Markowski J, Machnikowska-Sokolowska M, Milka D, Lepich T: Cephalic index in the first three years of life: study of children with normal brain development based on computed tomography. Scientific World Journal 2014: 502836, 2014

23. Matsuzawa J, Matsui M, Konishi T, Noguchi K, Gur RC, Bilker W, Miyawaki T: Age-related volumetric changes of brain gray and white matter in healthy infants and children. Cereb Cortex 11: 335-342, 2001

24. Muller HR, Brunholzl C, Radu EW, Buser M: Sex and side differences of cerebral arterial caliber. Neuroradiology 33: 212-216, 1991

25. Ogilvy CS, Tawk RG, Mokin M, Yang X, Levy El, Hopkins LN, Siddiqui $\mathrm{AH}$ : Stent-assisted coiling treatment of pediatric traumatic pseudoaneurysm resulting from tumor surgery. Pediatr Neurosurg 47: 442-448, 2011

26. Phillips TJ, Wenderoth JD, Phatouros CC, Rice $H$, Singh TP, Devilliers L, Wycoco V, Meckel S, McAuliffe W: Safety of the pipeline embolization device in treatment of posterior circulation aneurysms. AJNR Am J Neuroradiol 33: 1225-1231, 2012

27. Pistocchi S, Blanc R, Bartolini B, Piotin M: Flow diverters at and beyond the level of the circle of willis for the treatment of intracranial aneurysms. Stroke 43: 1032-1038, 2012

28. Rai AT, Hogg JP, Cline B, Hobbs G: Cerebrovascular geometry in the anterior circulation: An analysis of diameter, length and the vessel taper. J Neurointerv Surg 5: 371-375, 2013

29. Rizzi M, De Benedictis A, Marras CE, Palma P, Desiderio $F$, Rollo $M$ : Ruptured dissecting vertebrobasilar aneurysm in childhood: What is the therapeutic strategy? Pediatr Neurosurg 48: 313-318, 2012

30. Savastano LE, Chaudhary N, Gemmete JJ, Garton HJ, Maher CO, Pandey AS: Stent-assisted coil embolization of a symptomatic middle cerebral artery aneurysm in an infant. J Neurosurg Pediatr 14: 550-554, 2014

31. Sorteberg A, Dahlberg D: Intracranial Non-traumatic Aneurysms in Children and Adolescents. Curr Pediatr Rev 9: 343-352, 2013

32. Takegoshi H, Kikuchi S: An anatomic study of the horizontal petrous internal carotid artery: Sex and age differences. Auris Nasus Larynx 34: 297-301, 2007 
33. Takemoto K, Tateshima S, Golshan A, Gonzalez N, Jahan $\mathrm{R}$, Duckwiler G, Vinuela F: Endovascular treatment of pediatric intracranial aneurysms: A retrospective study of 35 aneurysms. J Neurointerv Surg 6: 432-438, 2014

34. Toyota A, Csiba L, Kollar J, Sikula J: Morphological differences in carotid angiograms and their relation to age. Orv Hetil 136: 1551-1554, 1995

35. Waitzman AA, Posnick JC, Armstrong DC, Pron GE: Craniofacial skeletal measurements based on computed tomography: Part II. Normal values and growth trends. Cleft Palate Craniofac J 29: 118-128, 1992

36. Wilms G, Buyse G, van Loon J, Maleux G: Treatment of a giant basilar artery aneurysm with a bridging stent and subsequent coil occlusion of the stent: Case report. Neurosurgery 67: E510-511, 2010

37. Wollschlaeger PB, Wollschlaeger G: Anterior cerebral-internal carotid artery and middle cerebral-internal carotid artery ratios. Acta Radiol Diagn (Stockh) 5: 615-620, 1966
38. Xavier A, Kansara A, Majjhoo AQ, Norris G: CT perfusion guided delayed recanalization with favorable outcome in pediatric stroke. J Neurointerv Surg 4: e33, 2012

39. Yu HJ, Kang IS, Lee M, Kim KH, Lee J: A successful treatment of arterial ischemic stroke with stent insertion in a child with congenital heart disease. Childs Nerv Syst 28: 1837-1841, 2012

40. Zarzecka A, Gory B, Turjman F: Implantation of two flow diverter devices in a child with a giant, fusiform vertebral artery aneurysm: Case report. Pediatr Neurol 50: 185-187, 2014

41. Zurada A, St Gielecki J, Tubbs RS, Loukas M, Zurada-Zielinska A, Maksymowicz W, Nowak D, Cohen-Gadol AA: Threedimensional morphometry of the $\mathrm{A} 1$ segment of the anterior cerebral artery with neurosurgical relevance. Neurosurgery 67: 1768-1782; discussion 1782, 2010 